\title{
DNA extraction from plant food supplements: Influence of different pharmaceutical excipients
}

\author{
Joana Costa ${ }^{\text {a }}$, Joana S. Amaral ${ }^{\text {a, b, * }}$, Telmo J.R. Fernandes ${ }^{a}$, Andreia Batista ${ }^{\text {a }}$, \\ M.Beatriz P.P. Oliveira a Isabel Mafra ${ }^{\text {a, }}{ }^{* *}$ \\ a REQUIMTE, Departamento de Ciências Químicas, Faculdade de Farmácia, Universidade do Porto, Rua de Jorge Viterbo Ferreira, 228, 4050-313 Porto, \\ Portugal \\ ${ }^{\mathrm{b}}$ ESTiG, Instituto Politécnico de Bragança, Campus de Sta. Apolónia, 5301-857 Bragança, Portugal
}

\section{A R T I C L E I N F O}

\section{Article history:}

Received 8 May 2015

Received in revised form

4 June 2015

Accepted 9 June 2015

Available online 12 June 2015

\section{Keywords:}

Plant food supplements

DNA extraction

DNA adsorption

Pharmaceutical excipients

Real-time PCR

\begin{abstract}
A B S T R A C T
The consumption of plant food supplements (PFS) has been growing globally, with an increase of misleading labeling and fraudulent practices also being reported. Recently, the use of molecular biology techniques has been proposed to detect botanical adulterations, one of the possible frauds in PFS. However, difficulties in recovering DNA from some PFS samples have been described. Aiming at using DNA-based methods for the unequivocal identification of plant species in PFS, adequate DNA isolation is required. However, PFS often contain pharmaceutical excipients known to have adsorbent properties that might interfere with DNA extraction. Thus, the aim of this work was to assess the effect of different excipients (talc, silica, iron oxide and titanium dioxide) on the recovery/amplification of DNA. For that purpose, known amounts of template maize DNA were spiked either to PFS or to model mixtures of excipients and quantified by real-time PCR. The tested excipients evidenced clear adsorption phenomena that justify the hampering effect on DNA extraction from PFS. The use of either $10 \%$ talc or $0.5 \%$ dyes completely adsorbed DNA, resulting in negative PCR amplifications. For the first time, pharmaceutical excipients were shown to affect DNA extraction explaining the inability of recovering DNA from some PFS samples in previous studies.
\end{abstract}

(c) 2015 Elsevier Ltd. All rights reserved.

\section{Introduction}

During the last years, medicinal plants and products thereof have become increasingly available in the European Union (EU) market as ingredients in formulations sold as plant food supplements (PFS). This type of products has been growing in popularity, with its increased use being associated with a variety of factors such as the perception that plant products are safe and that "natural" is healthy. The mistrust in conventional medicine and a rising tendency for self-medication are also associated factors [1]. Additionally, trade globalization has brought to Europe a wide range of plants traditionally used in other continents, which are now offered in several popular PFS marketed in European countries [1]. For these reasons, the market for food supplements has been growing

\footnotetext{
* Corresponding author. ESTiG, Instituto Politécnico de Bragança, Campus de Sta. Apolónia, 5301-857 Bragança, Portugal.

** Corresponding author.

E-mail addresses: jamaral@ipb.pt (J.S. Amaral), isabel.mafra@ff.up.pt (I. Mafra).
}

during the last years, with a consequent demand for plant material. This can result in a higher number of frauds and/or in increased possibility of unintentional swap of plants due to misidentification of wild collected specimens. Among possible adulterations of PFS, the intentional addition of plant fillers to increase product bulk and the substitution of high priced medicinal plants by other closely related/similar species should be considered $[2,3]$. In both cases, namely adulterations or unintentional swap of plants, the PFS integrity might be compromised by the introduction of unknown phytochemicals arising from the unlabeled plant(s), which can directly affect the PFS efficacy [4]. Furthermore, the safety of these products is also jeopardized since cases of possible health risks resulting from undeclared plants in PFS have already been reported $[5,6]$.

Therefore, to protect consumers, analytical methodologies that allow the identification of plant species, both in raw botanical materials and in the finished products/commercialized PFS, are required. So far, different methodologies have been proposed for the identification of plant species in PFS, including traditional 
methods such as morphologic evaluation (macro or microscopic observations) and chemical profiling [7-9]. Considering that these methods are not appropriated for PFS since they generally contain processed/powdered botanical mixtures [10] recent works have suggested the use of DNA molecules as diagnostic markers. As main advantages, these molecules are present in most cells and they are not affected by physiological plant conditions, unlike most phytochemical compounds [3,11,12].

DNA-based techniques are considered highly sensitive and specific tools, allowing the successful identification of plant species, even in complex and very processed samples [13-16]. However, up to date, most of DNA methodologies reporting the identification of medicinal plant species essentially concern botanical raw materials and traditional herbal medicines [17-19] with few works being developed for the authentication of PFS. Newmaster et al. [3] used DNA barcoding for the authentication of 44 herbal products (41 capsules, 1 tablet and 2 powders) sold in North-America and 50 leaf samples from different species. The authors were able to recover barcodes from DNA extracts of all leaf samples, whereas for herbal products the success rate was $91 \%$ (40/44 products). Wallace et al. [12] used DNA sequence information through standardized DNA barcoding aiming at the authentication of 95 natural health products, including 70 from plant origin (tea, liquids, root pieces, root slices, capsules, tablets and caplets). Although the authors used multiple markers and primer sets, they were unable to recover DNA barcodes from $25 \%$ of the plant products, from which two were plant roots, while fourteen were capsules, tablets or caplets. Thus, DNA amplification was not accomplished for a much higher number of pharmaceutical formulations (14 in a total of 33 capsules, tablets and caplets), when compared to samples of botanical materials ( 2 in a total of 35 samples of teas and roots). This difference of results can possibly be related to the fact that formulations of PFS frequently contain pharmaceutical excipients such as diluents, fillers, binders, glidants, lubricants, pigments and stabilizers [20]. In particular, some excipients used in the manufacturing of PFS, such as micronized talc (hydrated magnesium silicate) and silica (silicon dioxide), are known to have adsorbent properties. As a result, a hamper effect on the DNA extraction from PFS samples might occur, compromising the subsequent amplification. To the best of our knowledge, no studies have been carried out regarding the evaluation of possible interferences of pharmaceutical excipients on DNA extraction yields. Thus, the aim of this work was to ascertain the effect of different excipients (talc, silica, iron oxide and titanium dioxide) in the recovery/amplification of known amounts of maize DNA added either to PFS samples or to different mixtures of pharmaceutical excipients.

\section{Materials and methods}

\subsection{Samples of PFS}

PFS were acquired at local pharmacies or gently provided by some companies (DietMed, Portugal and Distrifa, Portugal). To evaluate the influence of pharmaceutical excipients commonly used in capsules and tablets, four PFS were carefully chosen in order to contain: talc and/or silica, titanium dioxide and/or iron oxide. One of the samples was also specifically chosen without containing any of the referred excipients for comparative purposes. None of the five PFS had maize starch included in their formulations. The complete description of each PFS composition is presented in Table 1. PFS were independently grinded and homogenized in mortars previously treated with DNA decontamination solution (DNA-ExitusPlus ${ }^{\mathrm{TM}}$, AppliChem, Darmstadt, Germany). To assess the effect of the matrix during DNA extraction, rice powder was also used.

\subsection{Mixtures of different pharmaceutical excipients}

Several mixtures containing different quantities of the pharmaceutical excipients under analysis, namely silica, talc, titanium dioxide and iron oxide, were prepared using microcrystalline cellulose as tablet/capsule diluent. The quantities of the excipients under study were chosen according to their specific functions in tablets/capsules formulations [20]. The complete description of the assayed mixtures of excipients is included in Table 2. Briefly, a total of eleven formulations were prepared using talc and/or silica as glidants/lubricant agents and titanium dioxide and/or iron oxide as dyes. Since cellulose is not described as having DNA adsorbent properties, it was used as a bulk excipient (100\% microcrystalline cellulose, without any of the tested excipients). Mixtures containing $1 \%$ and $10 \%$ of silica (M1, M2), $1 \%$ and $10 \%$ of talc (M3, M4), $1 \%$ of silica and $1 \%$ talc (M5), $0.5 \%$ and $1 \%$ of titanium dioxide (M6, M7), $0.5 \%$ and $1 \%$ of iron oxide (M8, M9) and $1 \%$ of titanium dioxide plus $1 \%$ of iron oxide (M10) were prepared in cellulose. The mixtures were independently homogenized in mortars previously treated with DNA decontamination solution (DNA-ExitusPlus ${ }^{\mathrm{TM}}$, AppliChem, Darmstadt, Germany).

\subsection{DNA extraction}

Portions of $100 \mathrm{mg}$ of each PFS (Table 1 ) or each pharmaceutical excipient mixture (Table 2), previously homogenized, were weighted in sterile reaction tubes. DNA was extracted using the commercial DNA extraction kit Nucleospin Plant II (Macherey-Nagel, Düren, Germany), according to the manufacturer's instructions with minor alterations. Before performing DNA extraction protocol, $100 \mu \mathrm{L}$ of maize DNA (50 ng) were added to each PFS, mixture or rice and incubated for $30 \mathrm{~min}$ at $37^{\circ} \mathrm{C}$ with soft stirring $(300 \mathrm{rpm})$. After the incubation step, $300 \mu \mathrm{L}$ of PL2 lysis solution pre-heated at $65{ }^{\circ} \mathrm{C}$ were added to each sample. After an incubation period of $1 \mathrm{~h}$ at $65{ }^{\circ} \mathrm{C}$ with continuous stirring (1000 rpm), $75 \mu \mathrm{L}$ of buffer PL3 were mixed in each tube and incubated for $5 \mathrm{~min}$ on ice to completely precipitate the SDS (sodium dodecyl sulphate). The samples were centrifuged at $11,000 \mathrm{~g}$, at room temperature for $2 \mathrm{~min}$, and filtered through the NucleoSpin filter. Then, $450 \mu \mathrm{L}$ of buffer PC (binding solution) were added to each lysate, mixed by gentle inversion and the volume eluted through a spin column (NucleoSpin Plant II Column) by centrifugation ( $1 \mathrm{~min}, 11,000 \mathrm{~g}$ at room temperature). The spin column was washed three times with $400 \mu \mathrm{L}$ of PW1 solution, $700 \mu \mathrm{L}$ and $200 \mu \mathrm{L}$ of PW2 solution, followed by 1 min of centrifugation after the two first washes and a 2 min final centrifugation $(11,000 \mathrm{~g}$ at room temperature). The elution step was performed twice with $50 \mu \mathrm{L}$ of PE solution at $65^{\circ} \mathrm{C}$, followed by $5 \mathrm{~min}$ of incubation at $65{ }^{\circ} \mathrm{C}$ and centrifugation ( $1 \mathrm{~min}, 11,000 \mathrm{~g}$ ), in order to maximize DNA yield. DNA extracts were immediately kept at $-20^{\circ} \mathrm{C}$ until further analysis. The extractions were performed at least in duplicate for each sample and mixture.

Yield and purity of extracts were assessed by $1 \%$ agarose gel electrophoresis and by UV spectrophotometric DNA quantification on a Synergy HT multi-mode microplate reader (BioTek Instruments, Inc., Vermont, USA), using a Take3 micro-volume plate accessory. DNA content was determined using the nucleic acid quantification protocol with sample type defined for double-strand DNA in the Gen5 data analysis software version 2.01 (BioTek Instruments, Inc., Vermont, USA).

\subsection{Real-time PCR}

Alcohol dehydrogenase gene ( $a d h)$ was chosen as a marker for maize quantification since it is considered a taxon-specific 
Table 1

Description of the plant food supplements (PFS) samples.

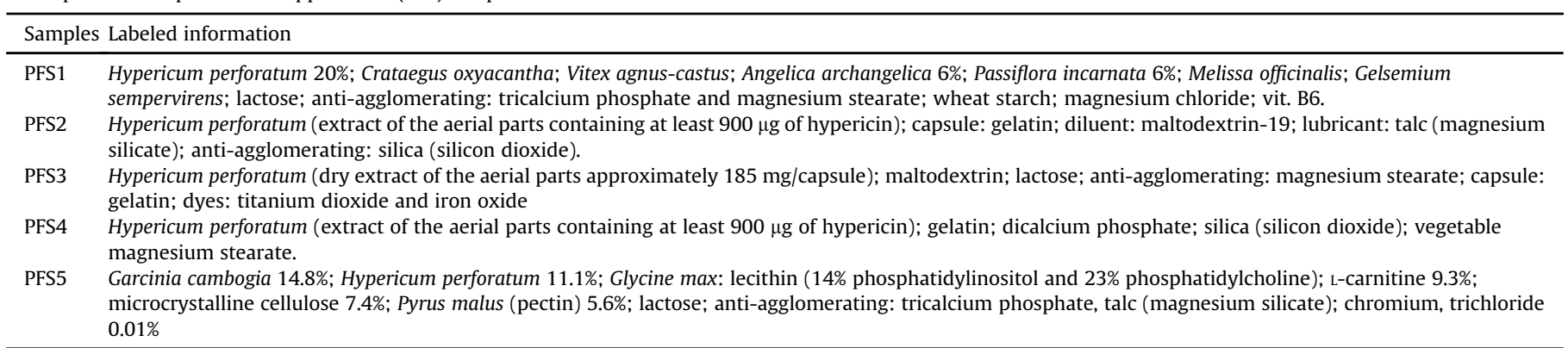

Table 2

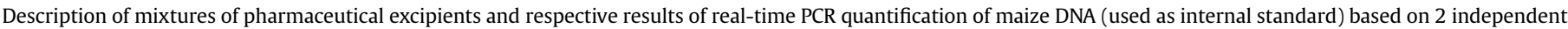
extractions with $n=8$ replicates.

\begin{tabular}{|c|c|c|c|c|c|c|}
\hline Mixtures & Spiked maize DNA (ng) & Composition of matrix & $\mathrm{Ct} \pm \mathrm{SD}^{\mathrm{a}}$ & $\mathrm{DNA} \pm \mathrm{SD}^{\mathrm{a}}(\mathrm{pg})$ & $\mathrm{CV}(\%)$ & DNA recovery (\%) \\
\hline Control & 50 & Water & $31.9 \pm 0.1$ & $418.2 \pm 34.7$ & 8.3 & 100 \\
\hline M0 (blank) & 50 & $100 \%$ Cellulose $^{\mathrm{b}}$ & $33.7 \pm 0.3$ & $121.4 \pm 24.9$ & 20.5 & 29.0 \\
\hline M1 & 50 & 99\% Cellulose, $1 \%$ silica & $33.8 \pm 0.5$ & $122.2 \pm 41.4$ & 33.9 & 29.2 \\
\hline M2 & 50 & 90\% Cellulose, $10 \%$ silica & $37.3 \pm 0.2$ & $10.3 \pm 1.4$ & 13.4 & 2.5 \\
\hline M3 & 50 & $99 \%$ Cellulose, $1 \%$ talc & $35.7 \pm 0.4$ & $29.9 \pm 8.8$ & 29.4 & 7.1 \\
\hline M4 & 50 & $90 \%$ Cellulose, $10 \%$ talc & NA & - & - & - \\
\hline M5 & 50 & $98 \%$ Cellulose, $1 \%$ silica and $1 \%$ talc & $34.6 \pm 0.5$ & $66.8 \pm 21.4$ & 32.0 & 16.0 \\
\hline M6 & 50 & 99.5\% Cellulose, $0.5 \%$ titanium dioxide & NA & - & - & - \\
\hline M7 & 50 & $99 \%$ Cellulose, $1 \%$ titanium dioxide & NA & - & - & - \\
\hline M8 & 50 & 99.5\% Cellulose, $0.5 \%$ iron oxide & NA & - & - & - \\
\hline M9 & 50 & $99 \%$ Cellulose, $1 \%$ iron oxide & NA & - & - & - \\
\hline M10 & 50 & $98 \%$ Cellulose, $1 \%$ iron oxide and $1 \%$ titanium dioxide & NA & - & - & - \\
\hline
\end{tabular}

a Cycle threshold $(\mathrm{Ct})$ values are mean $\pm \mathrm{SD}$.

b Negative results were obtained without template maize DNA; SD, standard deviation; CV, coefficient of variance; NA, no amplification.

(endogenous) gene for Zea mays L. For this purpose, specific primers (adh1-F, CCA GCC TCA TGG CCA AAG; adh1-R, CCT TCT TGG CGG CTT ATC TG) and probe (adh1-P, FAM-CTT AGG GGC AGA CTC CCG TGT TCC CT-BHQ1) targeting the adh1 gene were selected from the literature [21].

Amplifications by real-time PCR were performed in $20 \mu \mathrm{L}$ of total reaction volume containing $2 \mu \mathrm{L}$ of DNA extract, $1 \times$ of SsoFast $^{\mathrm{TM}}$ Probes Supermix, $200 \mathrm{nM}$ of each primer adh1-F/adh1-R and $100 \mathrm{nM}$ of adh1-P probe. The assays were carried out in a fluorometric thermal cycler CFX96 Real-time PCR Detection System (BioRad, Hercules, CA, USA) using the following conditions: $95{ }^{\circ} \mathrm{C}$ for $5 \mathrm{~min}$; 50 cycles at $95{ }^{\circ} \mathrm{C}$ for $15 \mathrm{~s}$ and $60{ }^{\circ} \mathrm{C}$ for $45 \mathrm{~s}$, with collection of fluorescence signal at the end of each cycle. Data were processed using the software Bio-Rad CFX Manager 3.1 (BioRad, Hercules, CA, USA). Each extract was amplified in quadruplicate in two independent assays.

\section{Results and discussion}

Following a preliminary study of our working group, in which several PFS were tentatively submitted to DNA extraction using different protocols (including in-house optimized extraction methods and different commercial kits) that frequently resulted in negative PCR amplification targeting a eukaryotic gene, we decide to investigate the reasons behind this finding. Although amplifiable DNA was extracted from several PFS, for others, negative results were always obtained, irrespectively of the extraction method used (unpublished data). In most of these PFS, the formulation label described the inclusion of fragmented aerial plant parts, so it was expectable the presence of extractable plant DNA. The PFS under analysis were capsules and tablets that generally contain additional materials, other than plants/plant extracts in their composition, such as binders, diluents, glidants, lubricants, colorants and stabilizers. When carefully analyzing the ingredient list of the formulations for which the extraction of amplifiable DNA was not accomplished, we realized that most PFS had in common the inclusion of some excipients, namely talc and silica. It is known that DNA can be adsorbed onto silica surfaces, being this phenomena the basis for DNA purification via solid-phase extraction used in several commercial DNA extraction kits, and also by using silica nanoparticles [22-24]. The adsorption of DNA onto the surface of silica nanoparticles used in DNA extraction from biological samples is mainly explained by weak electrostatic repulsion forces, dehydration and hydrogen bonds $[25,26]$. Moreover, it has also been proposed that adsorption of nucleic acids onto mineral surfaces can occur due to ionic interactions between the negatively charged phosphate groups of DNA and the positively charged surface groups [27]. Thus, taking into account the adsorbent properties of talc [28], it is possible that DNA could also be adsorbed to this excipient. Moreover, based on the excipients listed from non-amplifiable PFS extracts, other compounds, such as iron oxide and titanium dioxide, used as colorants (dyes) in some formulations, could also have a hampering effect on DNA extraction from PFS. According to the available literature, iron oxide magnetic nanoparticles have already been used for DNA adsorption to isolate it from mammalian cells [29] and from herring sperm [30]. The adsorption of fluorescent labeled DNA oligonucleotides on titanium dioxide nanoparticles has been shown to take place mainly via the backbone phosphate [31].

Therefore, in the present work we intended to evaluate if the referred pharmaceutical excipients (silica, talc, iron oxide and titanium dioxide) could be retaining DNA from PFS. For this purpose, five selected PFS samples and eleven model excipient mixtures were spiked with a known amount of maize DNA to work as an internal standard. The samples and mixtures were then submitted to DNA extraction and amplified by real-time PCR targeting a maize DNA fragment for quantification. 


\subsection{PFS samples spiked with maize DNA extract}

The five PFS under study included one sample (PFS1) that gave positive results for eukaryotic DNA amplification (using the method described by Costa et al. [32]) and did not refer any of the pharmaceutical excipients under evaluation, and four PFS (PFS2-PFS5) that gave unsuccessful DNA amplification (Table 1). To assess possible matrix effects, powdered rice was used as a non-interfering plant food matrix. Table 3 presents the results of the recovery assays of maize DNA in water (control without matrix), rice and PFS samples determined by quantitative real-time PCR. As can be observed, similar results were obtained for the control and the powdered rice (442.9 pg and 416.6 pg maize DNA, respectively). Taking the water control as reference, a high recovery of maize DNA (94\%) was obtained from the rice matrix, indicating a negligible effect of plant material on DNA recovery. However, a much lower maize DNA amount (184.2 pg) was obtained from the PFS1 sample, without any of the excipients under evaluation, thus suggesting the existence of a matrix effect on DNA amplification that causes some inhibition noticed in amplification curve profile. When compared to the control, more than $40 \%$ of maize DNA was still recovered from the PFS1. Regarding the other PFS, no DNA was recovered from the spiked samples containing either talc (PFS2, PFS5) and/or silica (PFS2, PFS4) in their composition, showing a complete retaining effect on maize DNA extraction (Fig. 1A). In the case of PFS3, containing titanium dioxide and iron oxide, only minute amounts of maize DNA (15.7 pg) were recovered. In this sample, titanium dioxide and iron oxide are most likely to be present at very low amounts since both compounds are generally used as coloring agents in pharmaceutical formulations $(\leq 1 \%)$. Possibly for this reason, the hampering effect on DNA extraction was not as strong as in the PFS containing either talc and/or silica, which are used at higher amounts (as lubricants, gliders, binders or diluents) [20].

\subsection{Mixtures of pharmaceutical excipients spiked with maize DNA extract}

Mixtures containing known amounts of the pharmaceutical excipients hypothesized to be responsible for adsorption phenomena were prepared using cellulose as diluent (Table 2). Identically to PFS samples, recovery assays were performed by adding known amounts of maize DNA (50 ng) to the model mixtures.

Since talc is widely used in oral solid formulations as lubricant (up to $10 \%$ ) or as diluent (up to $30 \%$ ) [20], initially, mixtures were prepared with $10 \%-30 \%$ of talc in cellulose. Additionally, previous mixtures containing $10 \%$ of talc added with different percentages of the other excipients, namely $1 \%$ and $10 \%$ silica; $0.5 \%$ and $1 \%$ coloring agents (titanium dioxide and iron oxide), were also prepared. In all these assayed mixtures, no DNA was recovered since no amplifications were obtained by real-time PCR targeting maize DNA, evidencing a total adsorption of the spiked DNA to the pharmaceutical excipients used (data not shown). Thus, new and different mixtures were prepared using lower amounts of each excipient under study. Table 2 shows the composition of each mixture and the respective maize DNA recovery results. As can be observed, a low DNA amount was recovered from the $100 \%$ cellulose material (blank) compared to the control (DNA in water), pointing to a possible interference of cellulose on DNA extraction (Fig. 1B). Comparatively to the blank material, all tested excipients showed the capacity to adsorb DNA, although with different degrees (Fig. 1B and C). Talc seems to exert a stronger hampering effect on DNA extraction than silica. The mixture containing $1 \%$ of talc (M3) showed minute amounts of recovered maize DNA (7.1\%), while the 10\% (M4) completely adsorbed it. The $1 \%$ silica (M1) enabled a similar amount of recovered DNA as the blank (MO), suggesting that at this level none or negligible adsorption effect occurred. When silica was increased to $10 \%(\mathrm{M} 2)$, there was a considerable DNA retention $(2.5 \%$ of recovery). Considering the mixture with both excipients at $1 \%$ (M5), the amount of recovered DNA reached an intermediate value (16.0\%) between M1 and M3 with $1 \%$ silica or $1 \%$ talc, respectively (Table 2). In this case, it was expected a higher retention effect than using only $1 \%$ of talc, which suggest that both excipients may interact and decrease the DNA adsorption.

Regarding the mixtures containing different amounts of the dyes titanium dioxide and iron oxide (M6-M10), no amplification was obtained, showing a complete DNA retention in all the cases (Table 2). These results are in good agreement with previous data that reported a very strong interaction between DNA and particles of cobalt ferrite (a compound composed of iron oxide) due to the high affinity of phosphate groups to iron oxides [22].

Generally, the results from model excipient mixtures (Table 2) support the findings obtained in the analyzed PFS (Table 3), regarding the presence or absence of the tested excipients. The presence of bulk or diluent agents such as cellulose (M0) or starch (PFS1) prompts high and close DNA adsorption phenomena. The absence of DNA amplification in the PFS2, PFS4 and PFS5 might be explained by the use of talc and/or silica at levels $\geq 10 \%$, while minute amount of recovered DNA in PFS3 might result from the presence of titanium dioxide and iron oxide at lower proportions than $0.5 \%$. It is also important to highlight that the presence of other non-tested components/excipients in the PFS formulations might contribute for synergic or antagonist interactions.

In conclusion, the results evidenced a clear adsorption phenomena with all the tested excipients (silica, talc, iron oxide and titanium oxide) that could justify the hampering effect on DNA extraction from PFS. Thus, when evaluating the results obtained for DNA analyses in PFS, researchers must consider the formulations and excipients described on the products label, as those can affect the outcome of analyses. Since most PFS are sold as capsules and tablets, which frequently include the tested pharmaceutical excipients, further research is required in order to identify a strategy to release plant DNA from such formulations for forthcoming authenticity purposes.

Table 3

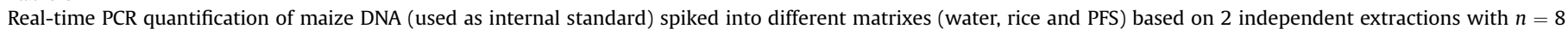
replicates.

\begin{tabular}{|c|c|c|c|c|c|c|}
\hline Matrix/sample & Spiked maize DNA (ng) & Pharmaceutical excipient under study & $\mathrm{Ct} \pm \mathrm{SD}$ & $\mathrm{DNA} \pm \mathrm{SD}^{\mathrm{a}}(\mathrm{pg})$ & $\mathrm{CV}(\%)$ & DNA recovery $(\%)$ \\
\hline Control (water) & 50 & - & $32.34 \pm 0.22$ & $442.9 \pm 64.9$ & 14.6 & 100 \\
\hline Rice flour ${ }^{\mathrm{b}}$ & 50 & - & $32.44 \pm 0.26$ & $416.6 \pm 72.6$ & 17.4 & 94.1 \\
\hline PFS1 & 50 & - & $33.63 \pm 0.09$ & $184.2 \pm 11.8$ & 6.4 & 41.6 \\
\hline PFS2 & 50 & talc and silica & NA & - & - & - \\
\hline PFS3 & 50 & titanium dioxide and iron oxide & $37.35 \pm 0.31$ & $15.7 \pm 4.6$ & 29.5 & 3.5 \\
\hline PFS4 & 50 & silica & NA & - & - & - \\
\hline PFS5 & 50 & talc & NA & - & - & - \\
\hline
\end{tabular}

a Cycle threshold $(\mathrm{Ct})$ values are mean $\pm \mathrm{SD}$

b Negative results were obtained without template maize DNA; SD, standard deviation; CV, coefficient of variance; NA, no amplification. 
A
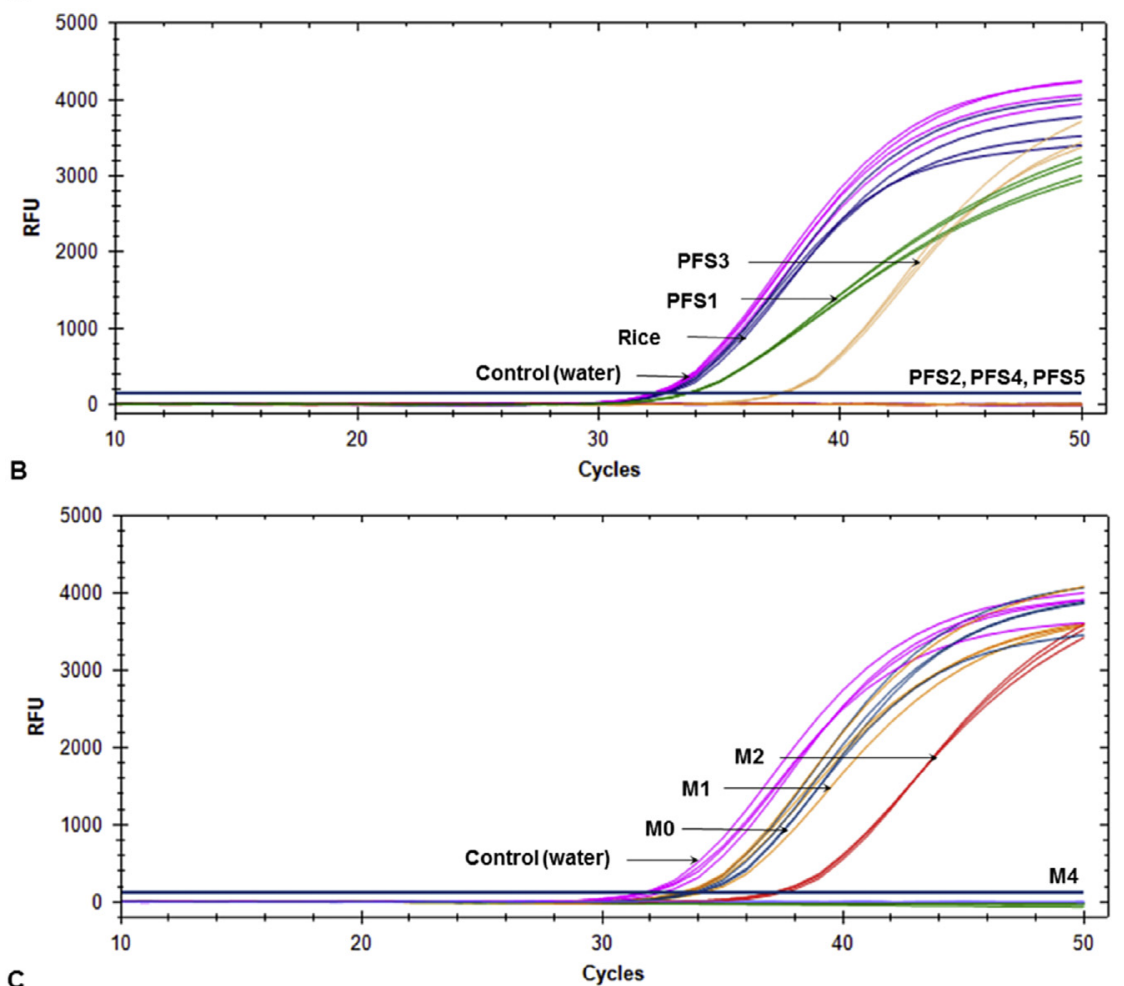

C

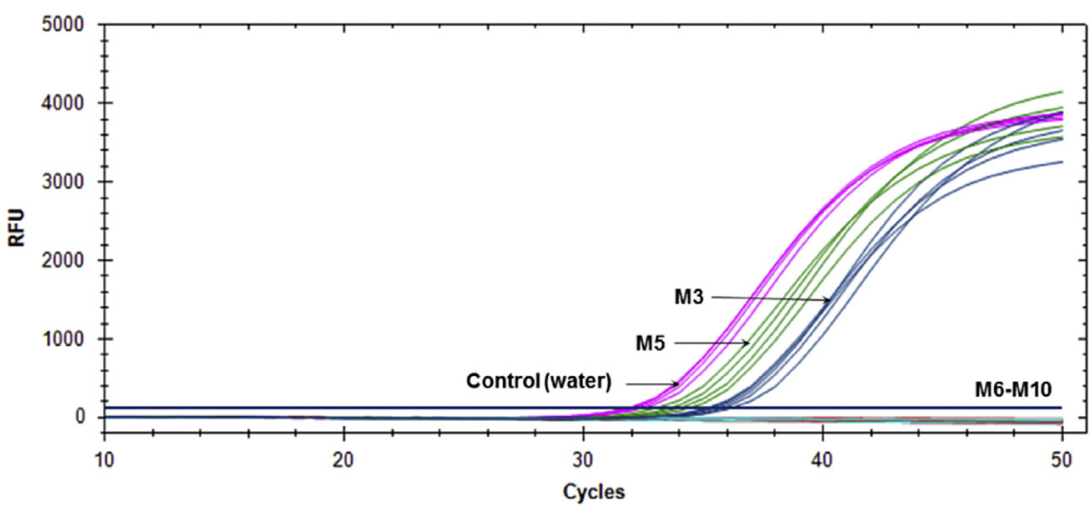

Fig. 1. Amplification curves obtained by real-time PCR targeting adh gene of maize used as internal DNA standard spiked to plant food supplements (PFS) (A) and to pharmaceutical model mixtures (B, C). PFS1-PFS5, samples of PFS as described in Table 1; M0-M10, model mixtures as described in Table 2.

\section{Acknowledgements}

This work received financial support from the European Union (FEDER funds through COMPETE) and National Funds (FCT, Fundação para a Ciência e Tecnologia) through project EXPL/DTPSAP/1438/2013 (Safety of plant food supplements: searching for adulterant pharmaceutical drugs and plants) and UID/QUI/50006/ 2013. Joana Costa and Telmo J.R. Fernandes are grateful to FCT grants SFRH/BPD/102404/2014 and SFRH/BD/93711/2013, respectively, financed by POPH-QREN (subsidized by FSE and MCTES).

\section{References}

[1] B. Egan, C. Hodgkins, R. Shepherd, L. Timotijevic, M. Raats, An overview of consumer attitudes and beliefs about plant food supplements, Food Funct. 2 (2011) 747-752.

[2] C. Franz, R. Chizzola, J. Novak, S. Sponza, Botanical species being used for manufacturing plant food supplements (PFS) and related products in the EU member states and selected third countries, Food Funct. 2 (2011) 720-730.
[3] S.G. Newmaster, M. Grguric, D. Shanmughanandhan, S. Ramalingam, S. Ragupathy, DNA barcoding detects contamination and substitution in North American herbal products, BMC Med. (2013) 11.

[4] M.R. Lum, E. Potter, T. Dang, D. Heber, M. Hardy, A.M. Hirsch, Identification of botanicals and potential contaminants through RFLP and sequencing, Planta Med. 71 (2005) 841-846.

[5] E. Gallo, E. Giocaliere, S. Benemei, A.R. Bilia, A. Karioti, A Pugi, M. di Pirro F. Menniti-Ippolito, G. Pieraccini, L. Gori, A. Mugelli, F. Firenzuoli, A. Vannacci, Anything to declare? Possible risks for patients' health resulting from undeclared plants in herbal supplements, Br. J. Clin. Pharmacol. 73 (2012) 482-483.

[6] M. Elvin-Lewis, Should we be concerned about herbal remedies, J. Ethnopharmacol. 75 (2001) 141-164.

[7] J. Sun, P. Chen, A flow-injection mass spectrometry fingerprinting method for authentication and quality assessment of Scutellaria lateriflora-based dietary supplements, Anal. Bioanal. Chem. 401 (2011) 1577-1584.

[8] C. Mathon, M. Duret, M. Kohler, P. Edder, S. Bieri, P. Christen, Multi-targeted screening of botanicals in food supplements by liquid chromatography with tandem mass spectrometry, Food Chem. 138 (2013) 709-717.

[9] H. Wohlmuth, K. Savage, A. Dowell, P. Mouatt, Adulteration of Ginkgo biloba products and a simple method to improve its detection, Phytomedicine 21 (2014) 912-918.

[10] N. Techen, I. Parveen, Z.Q. Pan, I.A. Khan, DNA barcoding of medicinal plant material for identification, Curr. Opin. Biotechnol. 25 (2014) 103-110. 
[11] J.J. Mihalov, A.D. Marderosian, J.C. Pierce, DNA identification of commercial ginseng samples, J. Agric. Food Chem. 48 (2000) 3744-3752.

[12] L.J. Wallace, S.M.A.L. Boilard, S.H.C. Eagle, J.L. Spall, S. Shokralla, M. Hajibabaei, DNA barcodes for everyday life: routine authentication of natural health products, Food Res. Int. 49 (2012) 446-452.

[13] J. Costa, I. Mafra, J.S. Amaral, M.B.P.P. Oliveira, Monitoring genetically modified soybean along the industrial soybean oil extraction and refining processes by polymerase chain reaction techniques, Food Res. Int. 43 (2010) 301-306.

[14] J. Costa, M.B.P.P. Oliveira, I. Mafra, Novel approach based on single-tube nested real-time PCR to detect almond allergens in foods, Food Res. Int. 51 (2013) 228-235.

[15] I. Mafra, I.M.P.L.V.O. Ferreira, M.B.P.P. Oliveira, Food authentication by PCRbased methods, Eur. Food Res, Technol. 227 (2008) 649-665.

[16] S. Soares, J.S. Amaral, M.B.P.P. Oliveira, I. Mafra, Improving DNA isolation from honey for the botanical origin identification, Food Control 48 (2015) 130-136.

[17] N.J. Sucher, M.C. Carles, Genome-based approaches to the authentication of medicinal plants, Planta Med. 74 (2008) 603-623.

[18] N. Techen, Z.Q. Pan, B.E. Scheffier, I.A. Khan, Detection of Illicium anisatum as adulterant of Illicium verum, Planta Med. 75 (2009) 392-395.

[19] G.S. Seethapathy, S.P. Balasubramani, P. Venkatasubramanian, nrDNA ITS sequence based SCAR marker to authenticate Aconitum heterophyllum and Cyperus rotundus in ayurvedic raw drug source and prepared herbal products, Food Chem. 145 (2014) 1015-1020.

[20] R.C. Rowe, P.J. Sheskey, M.J. Quinn, Handbook of Pharmaceutical Excipients, sixth ed., Pharmaceutical Press, London, 2009.

[21] JRC Reference Reports. Compendium of Reference Methods for GMO Analysis, European Union Reference Laboratory for Genetically Modified Food and Feed (EU-RL GMFF), 2011. Collaboration with the European Network of GMO Laboratories (ENGL), Eur24526 EN, http://gmo-crl.jrc.ec.europa.eu/ gmomethods/ (accessed on November, 2014).
[22] J. Prodelalová, B. Rittich, A. Spanová, K. Petrová, M.J. Benes, Isolation of genomic DNA using magnetic cobalt ferrite and silica particles, J. Chromatogr. A 1056 (2004) 43-48.

[23] E. Bogdanov, I. Dominova, N. Shusharina, S. Botman, V. Kasymov M. Patrushev, Silicon dioxide thin film mediated single cell nucleic acid isolation, PLOS ONE 8 (2013) e68280.

[24] P.E. Vandeventer, J. Mejia, A. Nadim, M.S. Johal, A. Niemz, DNA adsorption to and elution from silica surfaces: influence of amino acid buffers, J. Phys. Chem. B 117 (2013) 10742-10749.

[25] A. Bitar, N.M. Ahmad, H. Fessi, A. Elaissari, Silica-based nanoparticles for biomedical applications, Drug Discov. Today 17 (2012) 1147-1154.

[26] K. Melzak, Driving forces for DNA adsorption to silica in perchlorate solutions, J. Colloid Interface Sci. 181 (1996) 635-644.

[27] H.J. Cleaves II, E. Crapster-Pregont, C.M. Jonsson, C.L. Jonsson, D.A. Sverjensky R.A. Hazen, The adsorption of short single-stranded DNA oligomers to minera surfaces, Chemosphere 83 (2011) 1560-1567.

[28] N. Mutch, The silicates of magnesium, Br. Med. J 1 (1936) 143-148.

[29] Z.M. Saiyed, C. Bochiwal, H. Gorasia, S.D. Telang, C.N. Ramchand, Application of magnetic particles $\left(\mathrm{Fe}_{3} \mathrm{O}_{4}\right)$ for isolation of genomic DNA from mammalian cells, Anal. Biochem. 356 (2006) 306-308.

[30] M. Ghaemi, G. Absalan, Study on the adsorption of DNA on $\mathrm{Fe}_{3} \mathrm{O}_{4}$ nanoparticles and on ionic liquid-modified $\mathrm{Fe}_{3} \mathrm{O}_{4}$ nanoparticles, Microchim. Acta 181 (2014) 45-53.

[31] X. Zhang, F. Wang, B. Liu, E.Y. Kelly, M.R. Servos, J. Liu, Adsorption of DNA oligonucleotides by titanium dioxide nanoparticles, Langmuir 30 (2014) 839-845.

[32] J. Costa, M.B.P.P. Oliveira, I. Mafra, Effect of thermal processing on the performance of the novel single-tube nested real-time PCR for the detection of walnut allergens in sponge cakes, Food Res. Int. 54 (2013) 1722-1729. 